\title{
OS PROFESSORES E O MEDO DA MÍDIA*
}

\author{
Cláudio Márcio MagalHães \\ Centro Universitário UNA, Belo Horizonte, Minas Gerais, Brasil \\ WânIa Maria de Araújo \\ Universidade Estadual de Minas Gerais, Belo Horizonte, \\ Minas Gerais, Brasil
}

\begin{abstract}
Resumo: A mídia não só oferece representações do medo. Para alguns grupos sociais, ela é a fonte do medo. É o que acontece com os professores, que, tendo a concorrência da mídia e dos novos aparatos das Tecnologias de Informação e Comunicação (TIC) em sala de aula e extraclasse, sentem-se acuados, reagindo emocionalmente a uma aparente perda de espaço. $\mathrm{O}$ artigo pretende elucidar algumas possíveis origens desses medos e, por meio da informação e da quebra de preconceitos, iluminar possíveis caminhos a serem seguidos para reverter a sensação de medo diante das novas TIC. A pouca informação sobre o próprio conceito do medo, a divisão entre os campos da comunicação e educação, a má formação dos professores e o dilema da mudança de identidade são alguns dos fantasmas que assombram, e encará-los torna-se a principal estratégia para combatê-los.
\end{abstract}

Palavras-Chave: Comunicação. Medo. Professores. TIC.

\section{INTRODUÇÃO}

O medo e a mídia têm uma relação próxima. São várias as suas formas de representação. Mas o que dizer sobre o medo da mídia? Existirá, nestes tempos de "hegemonia midiática", já uma espécie de midiafobia? De qualquer forma, já há um grupo que sofre os sintomas há um bom tempo: a(o)s professora(e)s. $70 \%$ deles se sentem pouco ou nada preparados para o uso das TIC (LOPES et al., 2009, p. 4). Este artigo propõe, assim, tratar desse assunto, com suas principais causas e indicadores. Como qualquer medo, há

\footnotetext{
* Artigo recebido em 6/3/2014 e aprovado em 5/5/2014.
} 
mecanismos práticos que ajudam no seu combate e na sua superação. E os mais importantes são a informação e a quebra dos preconceitos.

\section{DOIS CASOS BASEADOS EM FATOS REAIS}

A professora Joana, do ensino básico de uma escola (aqui não importa se pública ou privada), está revoltada na sala dos professores. Reclama que as alunas não param de elogiar o ator Lázaro Ramos na nova novela da Globo, Lado a Lado. Dos garotos, ouviu de relance que as cenas da capoeira no mesmo folhetim é que estavam atraindo a atenção.

Segue-se a essas observações uma lista de desqualificações da TV um tanto conhecida: a primeira delas é a sua hegemonia na agenda dos jovens - acrescentadas pela extensão agora fornecida pela internet com fotos, resenhas dos capítulos, twiters dos admiradores e dos próprios atores e produtores, chats, comentários nas redes sociais, a lista não tem fim! Depois, há a sua manipulação de sentimentos, a alienação dos verdadeiros problemas, a supressão das alternativas de entretenimento, como livros, teatro, atividades ao ar livre. Por fim, mas não menos importantes, há a superficialidade, o desprezo e a irresponsabilidade com que a mídia popular trata a história, como no caso de Lado a Lado, que aborda o início da República e suas questões sociais mais relevantes, como a inserção dos ex-escravos na sociedade.

Em outra sala, desta vez em um curso superior, o professor Alberto explica as novas tecnologias que estão por vir. Uma delas é o e-code, uma reformatação do conhecido código de barras que promete trazer muito mais informações quando não ligar diretamente, via internet, o usuário e cliente às empresas. Essa é uma tecnologia nova e o professor Alberto confessa que não tem ainda muitas informações sobre ela, prometendo aos estudantes que, uma vez capacitado, trará para a sala de aula. Nesse momento, alguns alunos levantam a mão, pedem licença, sacam seus celulares, entram na internet e demonstram aos demais colegas o sistema, já instalado em seus aparelhos. Não há conotação, pelos estudantes, de superioridade, apenas um espírito de colaboração com o mestre, mas o Prof. Alberto fica arrasado. Parte da sua aula foi dada pelos mesmos alunos para os quais ele deveria ensinar os conhecimentos que acabou de aprender.

A revolta da Profa. Joana e a angústia do Prof. Alberto podem ter a mesma causa: o medo. Ou os medos. Porque podem ser classificados em diferentes gêneros. Desde o medo do novo, do desconhecido, que nos acompanha desde sempre, como o medo social de ser superado, de se tornar um pária entre os seus pares, ou mesmo o medo psíquico do desprezo, da 
perda da autoestima e da identidade tão arduamente construída como o sujeito responsável pela disseminação e incorporação do conhecimento.

É um medo paralisante e que nubla a razão e o entendimento. A professora Joana não percebe a oportunidade de utilizar algo que os jovens apreciam - e que os motiva - para empreender um conteúdo conhecidamente de difícil assimilação e de enorme importância para se compreender a realidade contemporânea. Já o professor Alberto desperdiça a oportunidade de interagir com os seus alunos de forma plena, ambos se reconhecendo como atores e público da mesma peça tecnológica, em que funções podem ser invertidas, a de detentor e receptor da informação, mas não os papéis de orientador e orientado.

Falta aos professores Alberto e Joana lembrarem que nossos medos fazem parte da nossa personalidade e são construídos e usufruídos pelos tempos e ambientes em que convivem. Motivados internamente pela combinação de variáveis sociais, psíquicas e genéticas, nossos medos transparecem pelas nossas reações perante aquilo que as estimula externamente. São nossas respostas ao meio ambiente. Podemos responder com agressividade ou com depressão. Mas é sempre uma tentativa de se voltar ao equilíbrio. Sendo a mídia o nosso problema, e sem qualquer esperança de que ela deixará de existir como fonte desses medos, a única alternativa é enfrentá-la. Não a mídia propriamente dita, que está aí porque a sociedade assim deseja e, portanto, não a vê como ameaça, muito pelo contrário. Mas os medos que sustentam a aversão a ela. No entanto, primeiro é preciso não ter medo do medo.

\section{O MEDO COMO UMA CONSTRUÇÃO SOCIAL}

A vida em sociedade é reveladora, entre outras coisas, do sentido que os indivíduos em um determinado momento do tempo e em um determinado território constroem sobre os acontecimentos e objetos que ali têm lugar. Com efeito, o que se pode perceber é que, ao longo da história da humanidade, os homens atribuíram e continuam atribuindo sentidos diversos às suas ações e aos artefatos materiais que delas se originam. Dentre esses acontecimentos que, de certa forma, poderíamos considerar como universais, a existência do medo, ou melhor, a sensação de medo é algo que acompanha os tempos e lugares onde os seres humanos vivem. Sendo assim, observa-se que os sentidos do medo podem, então, variar no tempo e nos lugares onde se instala, ou seja, cada cultura tem atribuído ao medo sentidos diversos, que, em geral, impulsionam ações, também diversas, no seu enfrentamento. 
De acordo com López (1988), o medo pode ser considerado como uma construção trans-histórica que emerge ou desaparece devido à relação real ou imaginária com o exterior. O medo faz parte de nossa natureza, mas seus sentidos e a forma de combatê-los são historicamente determinados pelas diferentes organizações sociais. É uma realidade e uma representação, e seu fundamento empírico serve como base e justificação para a construção de um imaginário sobre o medo. Ainda de acordo com López (1988), o medo opera como mediação simbólica entre o indivíduo e a sociedade e assim consolida crenças, dúvidas, fantasmas que comportam significações coletivas que são utilizadas para interpretar experiências. Ele pode ser palpável nos mais variados aspectos da vida cotidiana e produz formas subjetivas particulares. O impacto do medo pode ser caracterizado a partir de dois aspectos. São eles: 1) Transforma relações sociais e nessa transformação faz com que cada indivíduo possa ser vítima atual ou potencial, bem como um suspeito. Com isso, formas de solidariedade e identificação são desenvolvidas e coloca uns indivíduos contra os outros. 2) Pode criar novos lugares de encontro, novas formas de sociabilidade que geram proteção coletiva e mobiliza o grupo em torno do que se considera figuras do medo.

Esse imaginário do medo faz com que o Estado adote medidas autoritárias e leis punitivas, como resposta a uma demanda social de proteção imaginária ou real, principalmente dos setores médios da sociedade (TEIXEIRA; PORTO, 1998). É importante notar que essa postura do Estado acaba por justificar a existência de uma "indústria da segurança", com as grades, alarmes, seguros que, na prática, fornecem mais uma proteção imaginária do que real, visto que constantemente se noticia como esses sistemas são burlados. Na mesma medida, há um aumento das empresas de segurança privada e a discussão sobre o porte legal de armas.

A vida intra-muros não é um desejo, mas uma prevenção para evitar a vitimização. Os recursos possíveis do pertencimento a segmento médio, é investido na segurança material em que a grade e o alambrado se destacam na arte da proteção. (ECKERT, 2002, p. 28)

Sendo assim, os discursos políticos em momentos de eleição tomam o tema da segurança, por exemplo, como um alvo inevitável a ser atacado em face ao medo da população e ao clamor por mais segurança. Isso contribui, por um lado, para o fortalecimento de um imaginário da ordem, para a diminuição da vida coletiva em espaços públicos com o consequente "encarceramento" nos ambientes domésticos das prováveis vítimas da violência. Por outro lado, são constituídas redes de solidariedade como uma tentativa de resistência à 
diminuição dos espaços de liberdade, que, de alguma forma, expressam uma narração sobre o medo que é criada e recriada coletivamente.

Enfim, o medo gera ações ou, pelo menos, mobiliza os sujeitos para a ação, visto que historicamente podemos indicar diversas formas de agir frente às situações que geram medo, insegurança. Ou seja, o medo, para além de imobilizar os sujeitos, impulsiona-os a agir para construir bases e formas de enfrentamento das situações de conflito que o medo, real ou imaginário, instaura.

Mais um ponto que merece ser destacado em relação ao medo na sociedade contemporânea é como as formas de enfrentá-lo algumas vezes são construídas como novas práticas de violência (mesmo que não se configurem como violência física, instauram-se no campo da violência simbólica) de um grupo em relação a outro. Isso implica dizer que no cotidiano, principalmente das grandes cidades, os indivíduos têm construído formas de enfretamento do medo utilizando recursos tecnológicos para se sentirem mais seguros. Entretanto, ao mesmo tempo, observa-se também o acirramento de ações "separatistas", de isolamento e de estabelecimento de fronteiras materiais em relação àquilo ou àqueles que representam uma ameaça à segurança e que gera medo.

Além disso, face à discussão aqui proposta, é necessário pontuar como o medo tem rondado as escolas, seja devido às ações de violência que têm ocorrido nesse espaço da sociedade contemporânea, alcançando a relação aluno/professor, como também as relações entre os alunos. Essas ações de violência têm sido noticiadas pela mídia, em todas as suas modalidades, que se torna o caminho para conferir visibilidade a essas ações na sociedade e, em contrapartida, a própria mídia também tem sido objeto de temor em salas de aula. Com efeito, a mídia e seus produtos deixam de ser um elemento que interessa ao processo de aprendizagem e passam a ocupar o espaço de um vilão que atemoriza o professor e desestabiliza a tradicional relação de poder entre professor/aluno. Nesse sentido, não são poucos os fantasmas que habitam os casarões do medo dos professores no que se refere à mídia. Especificamente, selecionamos três deles que nos parecem serem os mais importantes a serem combatidos:

1. A herança histórico-social-cultural positivista que separou as áreas de comunicação e educação, tendo como mais nefasta consequência uma espécie de antagonismo entre elas, e a sublimação das características que as aproximam. Nesse clima de "Fla-Flu" epistemológico, professores e comunicadores se veem em campos opostos. Uma suposta hegemonia dos segundos - 
uma vez que estamos na era da informação e não da educação - constrange e amedronta ainda mais os primeiros, que se sentem excluídos destes novos tempos.

2. As políticas públicas, a infraestrutura das escolas e a formação deficiente dos professores no quesito mídia. Tanto no trato com a mídia como para a mídia. Os projetos de integração acadêmica e as escolas não são motivadores e os currículos de formação nos cursos de pedagogia raramente contemplam disciplinas que tratam da temática. As TIC ainda são vistas como o instrumental com fins didáticos: como usar o vídeo em sala de aula, como usar as histórias em quadrinhos em sala de aula, como usar o blog em sala de aula. Nas escolas e nas disciplinas dos cursos de licenciatura, os conteúdos são obrigatoriamente os que estão nos livros didáticos, passando ao largo do conhecimento já adquirido pelos alunos nos meios eletrônicos e até mesmo nos produtos de entretenimento. E ir a campo para batalha sem conhecimento prévio, certamente, é uma das variáveis mais importantes para o abastecimento do medo.

3. Os professores passam por um problema de mudança de identidade: de detentor do saber absoluto para o "mero" papel de catalisador e/ou facilitador e/ou orientador/tutor. Se racionalmente parece ser uma melhoria funcional, emocionalmente não é possível apagar centenas de anos atuando como farol de frotas e agora se transformar em uma seta de um barco individual. Mudanças dessa ordem podem gerar apreensão e medo.

\section{EDUCAÇÃO VERSUS COMUNICAÇÃO}

O positivismo, e sua prerrogativa de que "cada um deve ocupar o seu quadrado", ajudou a referendar a divisão entre áreas do saber. Duas delas, que tratamos neste trabalho, aparentemente ficaram em campos distintos. Mas se essa hipótese não é verdadeira, seria possível a existência de um romântico campo de conhecimento, que seja a sua amálgama um campo da Educação/ Comunicação?

Há uma forte linha de estudos e estudiosos do campo de saber denominado "educomunicação". Não somos especialistas para discutir a temática e nos importa aqui apenas: a) informar que essa questão existe e ela tem consequências no imaginário dos professores; b) que este trabalho é resultado dessa preocupação de aproximação dos campos, embora não 
se tenha como meta o cerne da questão, a criação ou sua consolidação como um novo campo; c) também informar qual a visão e quais as fontes de inspiração que temos sobre essa questão e de que forma isso pode contribuir para o esclarecimento e, consequentemente, para a iluminação das "trevas" da temática, fontes do medo dos docentes.

Tem-se em vista que o campo sempre existiu, desde que os homens perceberam que, por meio de representações gráficas gravadas em paredes, com técnicas instintivas de narrativa oral, era possível transferir, de uma geração a outra, os valores, as histórias e a maneira de viver de sua sociedade. Dessa forma, percebe-se que os homens têm utilizado a comunicação e a educação em benefício de sua perpetuação, sem se preocupar em separar uma da outra.

Na realidade, o que nos parece ser a questão central é voltar a pensar os dois campos novamente juntos, como antes de serem separados na primeira metade do século $X X$, quando da propagação dos meios de comunicação eletrônicos de massa. Certamente, os novos instrumentos da comunicação, como uma importante força motriz dos novos tempos, ganharam atenção especial e status suficiente para se transformarem em uma ciência específica, com seus pensadores, cientistas e pesquisas focados sobre os novos fenômenos midiáticos. Todavia, mais ainda porque visões, a princípio díspares, pontuaram o surgimento dessa nova ciência, fortalecendo a ideia de que, efetivamente, tratava-se de um campo do conhecimento que merecia seu próprio espaço de estudo, de conflito e de desenvolvimento.

O que realmente deu uma janela privilegiada à comunicação foram os estudos norte-americanos conhecidos como Mass Communication Research. Conforme Araújo (2001), os estudos se caracterizavam pela orientação empirista, privilegiando a dimensão quantitativa; pelo pragmatismo, mais político do que científico; pela prioridade para a comunicação mediática e baseado em apenas um modelo comunicativo: fonte de informação $\rightarrow$ transmissor $\rightarrow$ canal $\rightarrow$ receptor $\rightarrow$ destino. Ao contrário da Teoria Crítica, que discutia os novos meios de comunicação de massa sem destacar a comunicação como campo distinto, os pragmatismos dos estudos norte-americanos deram uma aura de especificidade à comunicação que contaminou as discussões a partir de então.

Lembremos que a educação é também herdeira desse modelo fordista, de produção em série e de aplicação de fórmulas pragmáticas. A ideia de "formação" permeia os objetivos da comunicação e da educação desde aqueles tempos, como agora. Conforme lembrado por Citelli (2002), o convívio entre a comunicação e a educação não é fato novo: 
O propósito de apreender as inter-relações entre os campos da comunicação e educação pode ser remontado às décadas de 30 e 40, e deriva das inquietudes geradas pela expansão dos media no século XX. A crescente presença da imprensa escrita, do rádio e, finalmente, da televisão mostrava estar se desenhando uma nova configuração nos conceitos de ensino/aprendizagem, de educação, de conhecimento. (CITELLI, 2002, p. 135)

Não que a comunicação não merecesse se constituir como campo autônomo, como ficou provado nos anos seguintes com trabalhos que fortaleceram o campo e o desprendeu do pragmatismo, (re)descobrindo novos estudos norte-americanos, contemporâneos ao da Mass Communication Research, mas muito mais próximos dos pensadores europeus, e caminhou como um campo do saber independente e vigoroso. No entanto, o próprio desenvolvimento dos meios de comunicação de massa obrigaria o seu estudo de maneira mais abrangente, englobando a educação em seu bojo.

Se olharmos, então, para a escola, percebemos a impossibilidade de desassociar os campos. Conforme Baccega (2003), tanto a escola quanto os meios de comunicação desempenham papéis sociais sintonizados nessa sociedade da informação e do conhecimento. Nesse sentido, é primordial a atualização recíproca de ambos os campos, o que acaba formando um só. Um campo que já existe, tanto pela existência dos meios de comunicação como educadores privilegiados, quanto pela necessidade premente de acioná-lo, dado o mundo "editado" em que vivemos, onde a interação entre a comunicação e a cultura aloja a conjunção da comunicação com a educação. A informação, essa moeda de circulação fácil e barata, embora seja um ótimo princípio, não é conhecimento. “O conhecimento implica crítica. Ele se baseia na inter-relação e não na fragmentação. Todos temos observado que essa troca do conhecimento pela informação tem resultado numa diminuição da criticidade" (BACCEGA, 2000, p. 106). Contribuindo com esse raciocínio de Baccega e já destacando a questão das novas tecnologias comunicacionais, Penteado assinala:

Inicialmente é preciso lembrar que as novas tecnologias comunicacionais são apenas e tão-somente prolongamentos refinados, recursos sofisticados, aptos a potencializar a capacidade comunicacional inerente ao ser humano, o que caracteriza como animal social por excelência e produtor de cultura. (PENTEADO, 1998, p. 13)

Assim como Penteado (1998), já não são poucos os educadores que defendem uma pedagogia da comunicação, uma vivência com uma didática que exercite a capacidade comunicacional do homem com a prática 
da educação como um processo específico de comunicação. Nessa direção, Porto pontua:

Na referida pedagogia os conhecimentos e a metodologia surgem a partir da dialogicidade do professor-comunicador com os alunos, destes entre si, e de ambos com os meios de comunicação disponíveis ao aluno em sua casa e no espaço escolar. (PORTO, 1998, p. 33)

O que, aparentemente, pode parecer uma obviedade - afinal, é claro que os professores devem se apropriar dos meios de comunicação em benefício de uma melhor educação - não o foi por muitas décadas dentro das salas de aula e nos meios de comunicação. Havia uma luta surda entre comunicadores e educadores. Para os primeiros, a educação e sua necessidade de sobrepor um extenso conteúdo reflexivo sobre a estética eram impraticáveis com os novos meios dinâmicos e rápidos da comunicação. Forçar esse paradigma era condenar o resultado a algo "chato". Já os educadores viam nos comunicadores sujeitos superficiais, que preconizavam a estética sobre qualquer conteúdo e que, portanto, a educação não se encaixaria nos moldes de como se mantêm os meios de comunicação. Forçar esse paradigma era condenar o produto educativo em algo superficial e alienante.

O resultado desse embate nas escolas, embora já se percebam avanços, ainda é bem conhecido de vários autores, como Ferrés (1996, p. 11), para quem "no meio escolar a tendência é adotar atitudes maniqueístas diante do fenômeno televisão". Em detrimento da TV e em função disso, como dito por Fischer (2001, p. 31-32), "a escola ainda não está suficientemente instrumentalizada para dirigir-se à 'criança telespectadora'". Já nos meios de comunicação, as experiências das TVEs são ainda mais ilustrativas. 0 lugar que deveria ser privilegiado, onde haveria espaço para os educadores e comunicadores exercerem sua interdisciplinaridade, sem as pressões comerciais e de audiência, em busca de um modelo integrado, mostrou-se um retrato fiel da dicotomia artificial entre comunicação e educação.

Criadas a partir dos anos de 1960, as televisões educativas (TVEs) têm refletido os momentos de discussão sobre televisão, comunicação e educação ao longo dos anos. Leite (1998) sintetiza em três momentos básicos essa relação entre a TV e educação: o da reprodução, o da crítica e o da complementariedade.

Inicialmente, tentou-se reproduzir a escola dentro das concepções de aprendizagem dominantes. Portanto, bastava colocar um professor na tela, encaixotar em módulos instrucionais e, se o aluno/telespectador prestasse atenção, o aprendizado aconteceria. Tal modelo repetiu-se em outros meios, 
como no Projeto Minerva nas rádios. A própria concepção da TV educativa está explícita na legislação que a funda, a qual não teve qualquer alteração posterior, e que define, pelo Decreto-Lei n. 236, de 28 de fev. de 1967, art. 130: "a televisão educativa se destinará à divulgação de programas educacionais, mediante a transmissão de aulas, conferências, palestras e debates". Para Leite,

Foi dessa época a gênese do preconceito (eu diria "pós-conceito") de que todo programa educativo é chato. Realmente era. Muitos ainda são, como ainda são maçantes as intermináveis aulas expositivas da maioria das nossas escolas. (LEITE, 1998, p. 61)

Com a inadequação do meio com a mensagem, pelo menos da maneira como se queria reproduzir a sala de aula dentro de um tubo de imagem, o movimento se dirigiu ao extremo e vive-se um período de crítica ideológica. A TV vira uma vilã, algo que corrompia as mentes inocentes e manipulava a massa a favor das forças dominantes. O ideal seria desligá-la e combatê-la com todas as forças.

No terceiro momento, vemos a tentativa de se construir, então, esse campo onde os conhecimentos se completam mesmo tendo, em muitas ocasiões, funções e finalidades distintas.

Certamente, não são momentos estanques. Castelo Rá-Tim-Bum e Cocoricó 1 são produtos modernos no sentido de unir o prazer de assistir a televisão com o apoio à educação formal e aconteceu nos primórdios das TVEs. $E$, ainda hoje, não faltam nem resistências à presença da TV no cotidiano das crianças, nem programas chatos na programação das televisões educativas. $O$ que importa aqui é que a construção desse campo da Educação/Comunicação é resultado de uma mudança de enfoque. A relação agora é o fundante da comunicação e dos objetos de estudo, não mais os sujeitos e os efeitos. E como lembra Quéré (1991), para se realizar um ato comunicativo é necessário uma certa "pertinência". Ou seja, para iniciá-lo e mantê-lo, é preciso disposição e interesse mútuo em se relacionar. Os conteúdos têm de refletir a história e os anseios de cada interlocutor, remetendo aos seus centros de referência. E isso é educação. Afinal, como lembramos em Larrosa (2003), educação é formar.

A formação não é outra coisa senão o resultado de um determinado tipo de relação com um determinado tipo de palavra: uma relação constituinte configuradora, aquela em que a palavra tem o poder de formar e transformar a sensibilidade e o caráter do leitor. Às vezes para tirar-lhe da indeterminação da infância, do espírito de criança. E às vezes, também, para dar ao seu espírito uma nova infância. (LARROSA, 2003, p. 46) 
Claro que esse leitor também é o "leitor" dos demais meios de comunicação. As mensagens, os conteúdos, surgem da/na relação dos sujeitos e, portanto, já antes do início do processo, mas também onde estão inseridos hoje, suas potencialidades de futuro e o que esperam um do outro e da relação em si.-

É o que podem fazer as alunas da Joana ao "darem de mamar" à sua boneca, após ver uma campanha de aleitamento na TV e escutar as explicações de sua mãe sobre o que faz o seu irmãozinho recém-nascido. Ou o aluno enterrar um osso de galinha e desenterrar um osso de dinossauro depois de ver um documentário sobre fósseis e ganhar um livro com ilustrações sobre o tema. Ou, ainda, estudantes escutarem na escola e ver na TV que alcoolismo é uma doença e que, assim, podem amar seu pai sem se culparem por isso.

\section{EsCOLA, POLÍTICAS PÚBLICAS E FORMAÇÃO}

Mesmo com grandes avanços e um notável amadurecimento dos professores, ainda há uma dicotomia entre as visões tecnofílicas ou tecnofóbicas (LITWIN, 2001; SANCHO, 1998). Nesse embate entre professores e mídia, entre o deslumbramento e a aversão, a não culpabilização faz parte da terapia para vencer o medo. Por parte dos professores, uma série de questões de formação, infraestrutura e habilidades não faz parte do seu cotidiano, haja vista alguns resultados apontados pela pesquisa TIC Educação 2011, realizada pelo Centro de Estudos sobre Tecnologias da Informação e da Comunicação (CETIC.BR) em escolas públicas de áreas urbanas brasileiras (BARBOSA, 2012). Foram entrevistados milhares de professores, alunos, diretores e coordenadores pedagógicos. Os resultados, em geral, mostram um professorado e suas escolas mais equipadas e dispostas a utilizarem as TIC, embora ainda sofrendo com a infraestrutura (número de computadores, manutenção, atualização e qualidade da banda larga). Particularmente, os professores, no seu uso cotidiano, já são $98 \%$ utilizando a internet, com $82 \%$ diariamente, $94 \%$ com computador em casa; deles, $89 \%$ com acesso à internet. Há, no entanto, barreiras a vencer:

- 39\% têm dificuldade ou nunca utilizaram programas de multimídia, som e imagem; 22\% têm dificuldade ou nunca copiaram um arquivo ou pasta.

- $20 \%$ nunca participaram de fóruns de discussão on-line e 19\% têm dificuldade em participar.

- 53\% têm dificuldade ou nunca baixaram e instalaram softwares e programas de computador.

- $25 \%$ não acessam a internet na escola. 
- Apenas $52 \%$ fizeram um curso específico de informática e, destes, $74 \%$ foram custeados pelo próprio professor.

Nas atividades no âmbito educacional e escolar, os professores encaram novos problemas:

- Suas maiores preocupações em relação aos objetivos pedagógicos são preparar os alunos para o mercado de trabalho (65\%), promover atividades relacionadas à vida cotidiana e prática dos alunos (63\%) e preparar os estudantes para um comportamento responsável (55\%).

- Apenas $28 \%$ gostariam de desenvolver nos alunos habilidades de comunicação e $26 \%$ de desenvolver nos alunos habilidades de colaboração - na realidade, as duas principais funções hoje requeridas das TIC pelos jovens.

- 57\% não usam a internet para pesquisa de informações em livros, revistas e/ou internet (dos professores que costumam realizar pesquisas de informações em livros, revistas e/ou internet durante o tempo de aula).

- $31 \%$ não utilizam trabalhos utilizando recursos multimídia (sons, vídeos, fotos).

- $64 \%$ usam do tempo em sala com computador e internet para ensinar como usar esse instrumental, mas apenas $43 \%$ para pesquisar informações e $39 \%$ para projetos ou trabalhos sobre um tema; ainda, apenas $27 \%$ para atividades em grupo, $24 \%$ para exercícios para a prática do conteúdo e $14 \%$ em apoio individualizado a alunos estudantes.

- No planejamento das aulas, apenas $61 \%$ realiza pesquisas em diversas fontes, $20 \%$ troca experiência com outros profissionais de outras escolas e apenas $4 \%$ produz material didático mais complexo, como apostilas e apresentações de slides, sites e softwares de criação.

Quanto à formação e ao apoio ao professor no uso do computador e internet:

- Apenas 22\% são apoiados por formadores da Secretaria de Ensino e 19\% por grupo de trabalho formado na própria escola para essa finalidade.

- $54 \%$ concordam que falta tempo para planejar aulas ou realizar outras atividades da escola usando computador e/ou internet e 57\% não participam de curso a distância (e-learning). 
- $70 \%$ acreditam que a falta de apoio pedagógico para o uso de computador e internet atrapalha.

Os coordenadores pedagógicos e as diretorias das escolas têm percepção ainda mais apurada:

- $37 \%$ dos diretores acreditam que os professores não sabem ao certo como lidar com o computador e a internet.

- $58 \%$ das escolas não têm programas de capacitação; apenas $37 \%$ estão no Prolnfo, o programa federal de capacitação em TIC.

- Apenas $29 \%$ dos coordenadores pedagógicos acreditam que, dentro dos seus objetivos pedagógicos, está o de preparar os alunos para que sejam competentes no uso da tecnologia.

- $62 \%$ das escolas não têm o uso do computador e internet como parte da grade curricular da escola.

- Apenas $24 \%$ das séries do ensino médio têm aulas de informática.

- $54 \%$ das escolas não permitem que os alunos utilizem os computadores fora de seu horário de aula, mas dentro do horário de funcionamento da escola; e $43 \%$ tem restrição ao número de horas que um aluno pode usar o computador.

- Apenas 53\% escolas têm website e, ainda assim, apenas para uso institucional e postagem de fotos, sem uso pedagógico.

Essa longa lista mostra um retrato que indica que as escolas, as políticas públicas e os professores estão contrapondo, em muitos momentos, educação, comunicação e tecnologia e considerando que conciliá-los é difícil. Felizmente, e aos poucos, esse pensamento tem mudado, mas com insistentes focos de resistência e, no novo espaço cibercultural, essas contraposições têm-se mostrado mais evidentes.

Aliás, é bem mais preocupante quando percebemos que a discussão parece apontar no mesmo rumo com a relação entre o uso das TIC no âmbito educacional. Geralmente, os primeiros movimentos percebidos na articulação dos novos artefatos tecnológicos no processo de ensino-aprendizagem são de salvação das más experiências educacionais vividas ao longo da história ou, pior ainda, de catástrofe e pessimismo. (MAGALHÃES; MILL, 2013, p. 320)

Esses novos movimentos são ainda mais novos motivos para o medo nos educadores. Na posição defensiva, os professores temem que as TIC levem os estudantes para o consumismo e reagem agressivamente, desqualificando as novas tecnologias como os responsáveis pela evasão escolar, senão fisicamente, psicologicamente, tornando-se ausentes mesmo em sala de aula. 
Além disso, conteúdos sobre mídia sequer compõem o quadro de disciplinas dos cursos de licenciatura e pedagogia e, quando o tema aparece, refere-se mais aos instrumentos e ferramentas que as mídias podem conter para uso didático. Mas como a presença da(s) mídia(s) na vida das pessoas tem sido cada vez mais ostensiva, tal temática deveria ser transversal às disciplinas e não um semestre dedicado a montar apresentações em power point ou construir um blog.

\section{IDENTIDADE EM QUESTÃO: DA BARSA PARA O GPS}

É notória a mudança - quando não a inversão - dos papéis na escola. Não é escopo deste trabalho a discussão sobre essa (re)construção da identidade do professor, visto que é uma temática complexa e abrangente que não cabe aqui discorrer. Mas nos cabe ratificar que não é confortável a queda do pedestal onde se encontrava o professor, aquele sujeito detentor do saber, fonte muitas vezes única do conhecimento, dividindo apenas com a família a hegemonia dos valores e saberes que norteariam a vida do jovem.

O professor está em plena fase de refletir em torno de sua identidade que, assim como as identidades na contemporaneidade são percebidas como fluidas, instáveis e em construção (HALL, 2005), não cabe mais ser professor desempenhando o papel de norteador e catalisador do saber. Nesse processo de reconstrução identitária, cabe mais ao professor se colocar junto com os alunos no processo de aprendizagem, estabelecendo efetivamente interação social e interação para a formação do saber. Conforme a pesquisa TIC Educação, $62 \%$ dos professores concorda que os alunos sabem mais sobre computador e internet do que ele. Assim, não faz mais sentido o professor se colocar naquele papel de enciclopédia, editando o conhecimento e fornecendo-o em conta-gotas ao aluno a partir da sua própria demanda editorial. Para continuar na analogia, cabe agora ao professor muito mais um papel de, digamos, GPS (a sigla é de Global Positioning System), aquele sistema de posicionamento global que abastece nossos celulares e mapas virtuais. O conhecimento enciclopédico está, agora, à disposição de todos, em várias mídias e suportes. Mas a indicação de qual o melhor caminho a tomar ainda é do professor/educador.

Dessa maneira, cabem aos professores Alberto e Joana não tratarem seus medos como um pesadelo petrificante, mas como incentivo a superá-los e a se superar. Não é fácil, como a superação de qualquer outro medo tão arraigado em questões históricas, sociais e culturais. Mas contam com a ajuda dos outros componentes dessa relação midiática complexa: os estudantes. A Profa. Joana, que, provavelmente como a maioria dos brasileiros, também 
deve gostar de novelas, deve encará-las como um apoio inesperado. Certamente Lado a Lado tem incorreções históricas e de abordagem, mas ninguém melhor do que ela para, justamente, apresentar as incorreções para discussão com seus alunos. Que tal chamá-los para escutar a resenha dos capítulos anteriores e, então, orientá-los sobre a temática? No manancial de conteúdos e interfaces que agora envolvem os folhetins televisivos, que tal colocar um "aplicativo" escolar, desenvolvido em parceira estudante/ professor/escola?

Prof. Alberto tem ainda uma missão mais fácil: a de se colocar como estudante para os seus "professores" de TIC. Sem culpa e medo, mas feliz por suscitar em seus "alunos tecnológicos" o pensar sobre o instrumento, a ferramenta, ao mesmo tempo que pratica e incentiva, in loco, o protagonismo desse sujeito.

Não é uma solução fácil, sabemos. Envolve sentimentos, história, preconceitos e aversões difíceis de serem desapropriados repentinamente. No entanto, é inegável a presença das mídias no nosso cotidiano e nos cabe pensar caminhos possíveis para dialogar com ela, tê-la como aliada nos processos educativos, tornando-os, inclusive, mais atrativos aos jovens. $\mathrm{E}$, quanto ao medo, a informação e o desejo de superação dão conta do resto.

\section{TEACHERS AND FEAR OF THE MEDIA}

ABSTRACT:The media does not just offer representations of fear. For certain social groups, it is the source of fear. Teachers who have to deal with competition from the media and the new devices for Information Technology and Communication (ICT) in the classroom and outside feel cornered and react emotionally to an apparent loss of space. This article discusses some possible origins of these fears, and through information and the breakdown of prejudices, points to paths that could be taken to dispel this feeling of fear in the face of the new ICTs. The dearth of information about the concept of fear itself, the artificial division between the fields of communication and education, inadequate formation of teachers and the dilemma of identity are some of the ghosts that haunt teachers.Knowing how to face them is the main strategy for fighting them.

KEY WORDS: Communication. Fear. Teachers. ICT.

\section{MAESTROS Y EL MIEDO DE LOS MEDIOS}

RESUMEN: Los medios de comunicación no sólo ofrecen representaciones del miedo. Para algunos grupos sociales, son la fuente del miedo. Esto es lo que les sucede a los profesores, quienes, enfrentando la competencia de los medios de comunicación y 
de los nuevos aparatos de las Tecnologías de la Información y Comunicación (TIC) en el aula y fuera de ella, se sienten acorralados y reaccionan emocionalmente a una aparente pérdida de espacio. Este artículo pretende aclarar algunos de los posibles orígenes de esos temores, y, por medio de la información y del rompimiento de prejuicios, iluminar posibles caminos a seguir para revertir la sensación de miedo frente a las nuevas TIC. La poca información sobre el propio concepto de miedo, la división entre los campos de la comunicación y de la educación, la mala formación de los docentes y el dilema del cambio de identidad son algunos de los fantasmas que rondan al profesor, y enfrentarlos se convierte en la principal estrategia para combatirlos.

Palabras claves: Comunicación. Miedo. Profesores. TIC.

\section{NOTA}

1. Produzidos pela TV Cultura de São Paulo e exibidos na maioria das emissoras educativas do país, são programas premiados no mundo todo pela sua concepção de entretenimento e objetivos educacionais que resultam em audiência significativa das crianças e resultados pedagógicos de destaque.

\section{REFERÊNCIAS}

ARAÚJO, C. A. A. A pesquisa norte-americana. In: HOHLFELDT, A.; MARTINO, L. C.; FRANÇA, V.V. (Org.). Teorias da comunicação: conceitos, escolas e tendências. Petrópolis, RJ: Vozes, 2001. p. 119-130.

BACCEGA, M. A. Comunicação/Educação: aproximações. In: BUCCl, E. (Org.). A TV aos 50: criticando a televisão brasileira no seu cinquentenário. São Paulo: Ed. Fundação Perseu Abramo, 2000. p. 95-109.

. Televisão e escola: uma mediação possível? São Paulo: Ed. Senac, 2003. (Série Ponto Futuro, 14).

BARBOSA, A. F. (Org.). Pesquisa sobre o uso das tecnologias de informação no Brasil: TIC Educação 2011. São Paulo: Comitê Gestor da Internet no Brasil, 2012.

CITELLI, A. Comunicação e educação: a linguagem em movimento. 2. ed. São Paulo: Ed. Senac, 2002.

DECRETO-LEl n. 236, 1967. Brasília: Congresso Nacional. Disponível em: <http://www. planalto.gov.br/ccivil_03/decreto-lei/del0236.htm>. Acesso em: 6 mar. 2014.

ECKERT, C. A cultura do medo e as tensões do viver a cidade: narrativa e trajetória de velhos moradores de Porto Alegre. Porto Alegre: Iluminuras, v. 3, n. 6, 2002. Disponível em: <http://seer.ufrgs.br/iluminuras/article/view/9141/5251>. Acesso em: 6 mar. 2014. FERRÉS, J. Televisão e educação. Porto Alegre: Artes Médicas, 1996. 
FISCHER, R. M. B. Televisão \& educação: fruir e pensar a TV. Belo Horizonte: Autêntica, 2001. (Coleção Temas \& Educação, 1).

HALL, S. A identidade na Pós-Modernidade. 10. ed. Rio de Janeiro: DP\&A, 2005.

LARROSA, J. Pedagogia profana: danças, piruetas e mascaradas. 4. ed. Belo Horizonte: Autêntica, 2003.

LEITE, M. Diretrizes e características de programação: teleducação. In: DE CARLI, A. M. S.; TRENTIN, A. N. (Org.). A TV da Universidade. Caxias do Sul: Ed. UCS, 1998. p. 59-63.

LITWIN, E. Das tradições à virtualidade. In: LITWIN, E. (Org.). Educação à distância: temas para o debate de uma nova agenda educativa. Porto Alegre: Artmed, 2001. p. 13-22.

LOPES, R.; FICHEMAN, I. K.; MARTINAZZO, A. A. G.; CORREA, A. G. D.;VENÂNCIO, V.; YIN, H. T.; BIAZON, L. C. O uso do computador e da internet na escola pública. [em linha] Laboratório de Sistemas Integráveis (LSI) do Departamento de Engenharia de Sistemas Eletrônicos da Escola Politécnica da Universidade de São Paulo, 2009. Disponível em: $<$ http://www.fvc.org.br/estudos-e-pesquisas/avulsas/estudos1-7-uso-computadores. shtml>. Acesso em: 6 mar. 2014.

LÓPEZ, M. M. Notre peur de tous les jours: I'imaginaire de l'insecurité et la militarisation de la vie quotidienne à Porto Rico. Comunicação apresentada no Colloque International de Sociologie de la Vie Quotidienne. Paris: Sorbonne, Université René Descartes, 1988. (Mimeo.).

MAGALHÃES, C. M.; MILL, D. Elementos para reflexões sobre educação, comunicação e tecnologia: nada é tão novo sobre redes, linguagem e aprendizagem. In: AZEVEDO, J.; MARTINS, M. L. Educação Temática Digital (ETD), Campinas, SP, Unicamp, v. 15, n. 2, maio/ago. p. 320-336, 2013.

PENTEADO, H. D. (Org.). Pedagogia da comunicação: teorias e práticas. São Paulo: Cortez, 1998.

PORTO, T. M. P. Educação para mídia/pedagogia da comunicação: caminhos e desafios. In: PENTEADO, H. D. (Org.). Pedagogia da comunicação: teorias e práticas. São Paulo: Cortez, 1998. p. 23-49.

QUERÉ, L. D'un modèle épistémologique de la communication à um modèle praxéologique. RESEAUX, n. 46/47, Paris, CNET, mar./abr. 1991. (Mimeo.).

SANCHO, J. M. Para uma tecnologia educacional. Porto Alegre: Artmed, 1998.

TEIXEIRA, M. C. S.; PORTO, M. R. S. Violência, insegurança e imaginário do medo. Campinas, Cadernos CEDES, ano XIX, n. 47, dez. 1998. Disponível em: <http://www.scielo. br/scielo.php?pid=S0101-32621998000400005\&script=sci_arttext >. Acesso em: 6 mar. 2014. 
ClÁudio MÁrcio MAgalHÃes é doutor em Educação e professor/ orientador do Mestrado em Gestão Social, Educação e Desenvolvimento Local e do Instituto de Comunicação e Artes do Centro Universitário Una. Autor de Os programas infantis na TV: teoria e prática para entender a televisão feita para as crianças. Ed. Autêntica, 2007.

E-mail: claudiomagalhaes@uol.com.br

WÂNIA Maria de Araújo é doutora em Ciências Sociais e professora/ orientadora do Mestrado em Gestão Social, Educação e Desenvolvimento Local e do Instituto de Comunicação e Artes do Centro Universitário Una e professora da Universidade Estadual de Minas Gerais (UEMG).

E-mail: wania.maria@yahoo.com.br 